\title{
HOMOSEXUALITY AND SOCIAL POLICY: THE CASE FOR A MORE INFORMED APPROACH
}

\author{
D.J. WEST* \\ I \\ INTRODUCTION
}

The criminal law does not regulate every aspect of behavior. Many choices are left to private morality, particularly issues on which opinions differ, such as drinking, smoking, interracial marriage, and the disciplinary rules applied by parents. This does not mean that law and morals are completely independent of each other; behavior that may ultimately cause demonstrable harm to individuals or to society at large is, and must be, restrained. Nonetheless, criminalization of an individual's behavior requires justification. Criminal justice operations are costly, not only financially, but also in damage caused to offenders, their families and associates, and sometimes their victims. This is especially true of prosecutions for sex offenses. Long ago, the Wolfenden Committee, ${ }^{1}$ set up to examine English law relating to homosexuality and prostitution, concluded that private, consensual, sexual relations between adults were not the law's business.

Legal permissiveness towards homosexuality, however, remains controversial because many believe that homosexual relationships are damaging. This is a matter for empirical study. This article argues that on balance the available evidence suggests that criminalization of homosexual behavior does more harm than good, and that the curtailment of civil rights on grounds of homosexual orientation is generally unjustified.

\section{II}

\section{Can Individuals Choose Their Sexual Orientation?}

Confusion surrounds the concept of sexual orientation. Initially, it may be misleading to divide the population into only two groups-homosexuals and heterosexuals-according to whether sexual arousal occurs solely or predominantly to persons of the same or of the opposite sex. While this seems a broadly correct generalization, there exists a minority capable of fully

\footnotetext{
Copyright (C 1988 by Law and Contemporary Problems

- M.D., Litt. D., F.R.C. Psych., Professor Emeritus of Clinical Criminology, University of Cambridge, Institute of Criminology.

1. Committee on Homosexual Offences and Prostitution, Report 24 (1957) [hereinafter WOLFENDEN REPORT].
} 
satisfying sexual interactions with both males and females. ${ }^{2}$ Indeed, some of these bisexuals may feel deprived if they cannot have access to both varieties of sexual experience. ${ }^{3}$ Even a tripartite division into heterosexuals, bisexuals, and homosexuals, however, hardly does justice to the variety of human sexual inclinations and behaviors. For some people with a homosexual orientation, for instance, the pleasure obtained by assuming the dress and manners of the opposite sex is as important as physical sexual contacts. ${ }^{4}$ Many male transvestites desire sexual intercourse with a woman in spite of an urge to wear feminine underwear during the process. ${ }^{5}$ Ultimately, as an index of current sexual practice, the best categorization may be that suggested by Kinsey, who ranked the population along a continuum from exclusively heterosexual to exclusively homosexual, with a substantial proportion somewhere in between the two. ${ }^{6}$

Protagonists of gay liberation dislike causal explanations of sexual orientation that deny individual freedom of choice, preferring "social constructionist" or "self-labelling" theories. ${ }^{7}$ Nevertheless, sympathy for the situation of the homosexual minority might be increased by the thought that many of them have no power to change. The available evidence suggests that sexual orientation is almost certainly the result of a complex interaction between biological predilections and environmental circumstances. For instance, an early mismatch between the attitudes and interests considered appropriate to a child's gender and his or her predilections is a well-known precursor of adult homosexual orientation, especially among primary homosexuals and especially in males. ${ }^{8}$ Not all adult homosexuals recall such gender dysphoria, however, and many who experienced it as children do not continue to manifest it as adults, even when homosexually oriented. ${ }^{9}$

A great deal of research has been directed towards discovering anatomical or endocrinological differences between heterosexuals and homosexuals analogous to the biological differences between males and females. The results so far are inconclusive. Brain cells regulating reactions to hormones function differently in males and females. The differentiation occurs during

2. W. Masters \& V. Johnson, Homosexuality in Perspective 166-73 (1979).

3. Lourea, Psycho-Social Issues Related to Counseling Bisexuals, in Bisexualities: Theory and Research 51, 59 (F. Klein \& T. Wolf eds. 1985) [hereinafter Bisexualities]; Matteson, Bisexual Men in Marriage: Is a Positive Homosexual Identity and Stable Marriage Possible?, in Bisexualities, supra at 149, 169.

4. R. Langevin, Sexual Strands: Understanding and Treating Sexual anomalifs in Men 186 (1983).

5. Prince \& Bentler, Survey of 504 Cases of Transvestism, 31 Psychological Rep. 903, 913 (1972).

6. A. Kinsey, W. Pomeroy \& C. Martin, Sexual Behavior in the Human Male 636-38 (1948).

7. McIntosh, The Homosexual Role, 16 Soc. Probs. 182, 184 (1968). See also Hart, Therapeutic Implications of Viewing Sexual Identity in Terms of Essentialist and Constructionist Theories, $9 \mathrm{~J}$. Homosexuality, Summer 1984, at 39. Hart notes, however, that at least some segments of the gay media endorse causal explanations of homosexual behavior that do deny individual freedom of choice. Id. at 42-43.

8. R. Green, The Sissy Boy Syndrome and the Development of Homosexuality 99-113 (1987).

9. Id. at 258. Carrier, Childhood Cross-Gender Behavior and Adult Homosexuality, 15 Archives Sexual Behav. 89, 91-92 (1986). 
embryonic development, and could be interfered with by the administration of hormones to the pregnant mother. ${ }^{10}$ Some researchers have advanced a fault in brain sex differentiation in the embryo, identifiable in adult male homosexuals by virtue of their characteristically anomalous response to an injection of estrogen, as one possible cause. ${ }^{11}$ More recent research, however, has challenged this theory. ${ }^{12}$ Evidence from studies of twins points to the contribution of a hereditary factor, at least in male homosexuality. ${ }^{13}$

Despite this evidence that biological factors determine sexual preference, upbringing must play an important part as well. A fraught relationship with father frequently occurs in the histories of both lesbians and male homosexuals. ${ }^{14}$ While it is possible that parental attitudes are not so much causes of homosexuality as reactions to the child's unwelcome attributes, the influence of upbringing is supported by clinical experience with transsexuals suggesting that attempts to treat a boy like a girl, or vice versa, can produce strong cross gender identification. ${ }^{15}$ Moreover, children with ambiguous genital anatomy, who have been reared contrary to their true biological sex, may develop an orientation congruent with how they have been brought up. ${ }^{16}$

Whatever the source of one's sexual orientation, it is clear that sexual behavior can reflect opportunity and circumstance as much as true preference. For example, in societies which set great store on virgin brides, wifely fidelity, and the seclusion of women (as in many Arab countries), many men who count themselves heterosexual are prepared to use other males as substitutes for unavailable women, usually choosing younger males for the purpose, and insisting on the masculine, penetrating role in sexual activity. ${ }^{17}$ In Saudi Arabia, for instance, a substantial proportion of young males in penal detention are there for homosexual offenses. ${ }^{18}$ In that country, premarital sex is forbidden, marriage is often delayed for economic reasons, and young women are carefully shielded by their families. Thus, boys are more accessible, and sexual assaults on them are more frequent than assaults on women. ${ }^{19}$ Similarly, men confined for long periods in sex segregated prisons and other institutions will resort to homosexual practices in which they would

10. J. Durden-Smith \& D. deSimone, Sex and the Brain 107-08 (1983).

11. Gladue, Green \& Hellman, Neuroendocrine Response to Estrogen and Sexual Orientation, 225 SCIENCE 1496 (1984).

12. Gooren, The Neuroendocrine Response of Luteinizing Hormone to Estrogen Administration in Heterosexual, Homosexual, and Transsexual Subjects, 63 J. Clinical Endocrinology \& Metabolism 583 , 584-86 (1986).

13. Eckert, Bouchard, Bohlen \& Heston, Homosexuality in Monozygotic Twins Reared Apart, 148 Brit. J. Psychiatry 421, 422-24 (1986).

14. D.J. West, Homosexuality Re-Examined 86-94 (1977)

15. I R. Stoller, Sex and Gender: The Development of Masculinity and Femininity 93-94, $102,119-20(1968)$.

16. J. Money \& A. Ehrhardt, Man \& Woman, Boy \& Girl: The Differentiation and Dimorphism of Gender IDENTITY from Conception to MATURity $117-25$ (1972).

17. V. Bullough, Sexual Variance in Society and History 224, 238 (1976).

18. Personal Communication with Dr. S. Malik, Research Centre for Crime Prevention, Riyadh, Saudi Arabia (Nov. 1987).

19. Id. 
never indulge under conditions of freedom..$^{20}$ In Britain, poverty and broken homes generate uneducated, unemployed, and homeless youths, some of whom, regardless of their own heterosexual inclinations, resort to male homosexual prostitution as a means of securing desperately needed emotional and financial support. ${ }^{21}$

The influence of the relative availability of homosexual and heterosexual contacts on the incidence of homosexual behavior is not necessarily inconsistent, however, with the notion that most people experience a strong and lasting difference in arousability to male and female sexual partners. Within the total range of sexual variation, it is possible to identify a hard core of primary homosexuals who have at no time in their lives been attracted to the opposite sex, while experiencing, since puberty or earlier, strong feelings, both physical and emotional, towards members of their own sex. ${ }^{22}$ They often attempt heterosexual relations during adolescence, but give them up because they find them unsatisfying. ${ }^{23}$ They frequently describe having been aware of a subtle difference between themselves and their schoolfellows. ${ }^{24}$ In our culture crude genital displays, sexual horseplay, and communal masturbation occur more often between young boys than among girls. ${ }^{25}$ The homosexual male may discover he is different because his reactions to these activities are more intense and emotional. Sometimes these reactions are so intense and emotional that to conceal his deviance the homosexual may withdraw from the others. This withdrawal has the paradoxical result that he may reach later adolescence with fewer juvenile homosexual contacts than many of his heterosexual peers. An example of this occurs in the posthumously published autobiography of $\mathrm{J}$. Addington Symonds, the well known nineteenth-century aesthete and litterateur. He describes his earliest sexual fantasies and his subsequent adult practice as obsessively homosexual, yet he also recalls being greatly shocked when exposed to the uninhibited sexual frolics of his male schoolfellows at Harrow. ${ }^{26}$

Additionally, for most people sexual orientation remains distinct and fixed throughout adulthood. Because of social pressure towards conventional family living, some homosexual individuals marry and have conjugal relations without deriving much pleasure from them. ${ }^{27}$ Indeed, these marriages are rarely happy ones, ${ }^{28}$ and if a need for contact with someone of their own sex

20. W. Wooden \& J. Parker, Men Behind Bars 13-18 (1982).

21. McMullen, Youth Prostitution: A Balance of Power, $10 \mathrm{~J}$. Adolescence 57, 69 (1987).

22. M. Feldman \& M. MacCulloch, Human Sexual Behaviour 149-50 (1980).

23. A. Bell, M. Weinberg \& S. Hammersmith, Sexual Preference: Its Development in Men AND WOMEN 113 (1981).

24. Id. at 81

25. Langfeldt, Childhood Masturbation: Individual and Social Organization, in Childoren and Sex: New Findings, New Perspectives 63, 66-68 (L. Constantine \& F. Martinson eds. 1981).

26. J. Addington Symonds, The Memoirs of John Addington Symonds 94-96 (1984).

27. M. Saghir \& E. Robins, Male \& Female Homosexuality: A Comprehensive Investigation $96,98,256(1973)$.

28. See generally Ross, Modes of Adjustment of Married Homosexuals, 18 Soc. Pross. 385 (1971). 
develops, the marriage is likely to break up. ${ }^{29}$ In such cases, one suspects the existence of an unacknowledged homosexual preference all along.

These cases and other evidence indicate that even extensive sexual behavior in response to the available opportunities does not alter one's true preference. Young heterosexual men can work successfully for years as prostitutes for other men, without becoming homosexual, spending their earnings on girl friends. ${ }^{30}$ One published case shows how a man attracted to adolescent boys, and who understands their enthusiasm for sexual instruction and experimentation, can have sexual friendships with hundreds of them, apparently without hampering the natural development of their heterosexual interests. ${ }^{31}$ In ancient Greece, sex between a younger man and an older male patron or instructor was a widespread practice, but it in no way supplanted heterosexual and family living. ${ }^{32}$ Anthropologists have described societies which, far from regarding homosexual intercourse as a bar to heterosexual development, insisted upon it before a young man could achieve full adult status and eligibility for marriage. ${ }^{33}$

Human sexuality, in spite of its importance in everyday life, and in spite of the vast volume of literature devoted to it, remains from a scientific standpoint poorly understood and comparatively little investigated. Current research provides no simple or conclusive answers to the practical question of how young people might help themselves or be influenced by others to acquire a socially approved sexual orientation. Social policy must rely, therefore, on tentative evaluations of what knowledge is so far available. The indications are that most people show a definite, possibly innate, tendency to heterosexual responsiveness which often develops before puberty and stays unchanged by casual homosexual encounters. A minority have an equally strong converse disposition, manifested more often and at an earlier age among males, and equally unaffected by attempts at heterosexual intercourse. Although some people change their sexual habits through force of circumstances, through conditioning treatment, or by overcoming inhibitions, there appears to exist a group of primary homosexuals who start off and remain throughout life much more readily aroused by their own sex than by

29. M. Saghir \& E. Robins, supra note 27, at 96-98, 256-58; see also M. Ross, The Married Homosexual Man 35-37 (1983); but see Brownfain, A Study of the Married Bisexual Male: Paradox and Resolution, $11 \mathrm{~J}$. Homosexuality, Spring 1985, at 173, 181. Brownfain reports the results of a study revealing that, though some do break up, many homosexual or bisexual men are able to pursue sex with other men without disrupting their marriages.

30. Coombs, Male Prostitution: A Psychosocial View of Behavior, 44 AM. J. Orthopsychiatry 782, 787 (1974).

31. P. Wilson, The Man They Called a Monster: Sexual Experiences Between Men and Bors 13-83 (1981).

32. See generally K. Dover, Greek Homosexuality (1978); A. Karlen, Sexualty and Homosexuality: A New View 12-43 (1971).

33. See generally G. Herdt, Guardians of the Flutes: Idioms of Masculinity (1981). The practice was supported by the belief that intake of semen aided the development of strength and potency. See G. Herdt, Rituals of Manhood: Male Initiation in Papua New Guinea 8 (1982); $c f$. R. Stoller, supra note 15, at 126 (Some Kukukuku people of the New Guinea highlands esteem oral homosexual relations because ingesting semen is believed essential to strength, virility, and growth into manhood.). 
the opposite sex, and who resist every opportunity, encouragement, or social pressure to react differently.

III

\section{Does Homosexual Behavior Result in Demonstrable Harm?}

\section{A. The Floodgate Theory}

In the years between the publication of the Wolfenden Report, which advocated decriminalization of private, consensual, adult male homosexual behavior in England, ${ }^{34}$ and the passing of the Sexual Offences Act of 1967, ${ }^{35}$ which implemented that recommendation, there was much discussion of the "floodgate" theory. This theory acknowledged that a small minority of practicing homosexuals who keep to themselves and avoid public display posed little threat, but predicted that legal permissiveness would lead to a great and embarrassing upsurge in the numbers of homosexuals. ${ }^{36}$ Experience has proved these fears groundless. After passage of the Sexual Offences Act, although the presence of the homosexual minority became more openly acknowledged, and gay rights issues became the subject of political debate, there have been no reports of any substantial increase in the size of the homosexual minority.

Although few cross-cultural studies have been conducted, no obvious correlation exists between the strength of anti-homosexual legislation and the size of the hard core homosexual minority. One examination of the numbers of homosexual meeting places in the cities listed in the Spartacus Gay Guide ${ }^{37}$ found that the number of gay meeting places tended to vary in proportion to the size of the population. This suggests that the homosexual minority represents a fairly constant percentage of the community, regardless of differing criminal laws. ${ }^{38}$ These investigators conducted surveys in towns in Brazil, Guatemala, the Philippines, and the United States. ${ }^{39}$ They concluded that, after discounting casual homosexual behavior by predominantly heterosexual men, the proportionate size of the male homosexual minority was much the same in these very different communities. ${ }^{40}$ Moreover, questionnaire findings from the same study indicated that three-quarters of self-identified homosexuals, regardless of nationality, had first felt attracted to their own sex when they were under fourteen years of age, and many when

34. WOLFENDEN REPORT, supra note 1 , at 115.

35. Sexual Offences Act, 1967, ch. 60, $\$ 1$.

36. See, e.g., the account of the House of Lords debate of May 12, 1965, in H. Montcomery Hyde, The Love That Dared Not Speak Its Name 262-63 (1970).

37. SPartacus International Gay Guide (16th ed. 1986). For a discussion of the origins of this publication, see J. Weeks, Coming Out: Homosexual Politics in Britain, from the Nineteenth Century to the Present 180 (1977).

38. F. Whitam \& R. Mathy, Male Homosexuality in Four Societies: Brazil, Guatemala, The Phillippines, and the United States 9 (1986).

39. Id. at xxi-xxxii.

40. Id. at 8-9. 
they were under seven. ${ }^{41}$ In none of the four surveys were significant differences found between the ages of the homosexuals' first attraction to males and heterosexuals' first attraction to females. ${ }^{42}$ These results, and also the authors' analyses of historical and anthropological accounts of manifestations of homosexuality, accord with the hypothesis that the incidence and development of primary homosexuality is substantially independent of legal pressures. Indeed, in Scandinavian and other countries, long standing policies of tolerance have not produced disruption or noticeably homosexual ridden communities. That is, it seems that there are not great numbers of homosexuals awaiting release from legal floodgates.

In light of these considerations, severely intolerant policies towards homosexual behavior-for example, extermination of .homosexuals in concentration camps in Hitler's Germany, ${ }^{43}$ or even the U.S. Senate committee recommendation in the 1950's that homosexuals be dismissed from government employment ${ }^{44}$ - seem as unnecessary as they are abhorrent.

\section{B. Seduction of the Young}

The belief that homosexuality is spread by proselytism and seduction, and that the young are particularly vulnerable to these influences, has been an important factor in the demand for rigorous social control. Thus, in 1954, the Home Secretary, emphasizing his opposition to relaxation of the law against homosexuality, declared that "[h]omosexuals, in general, are exhibitionists and proselytizers and a danger to others, especially the young." 45 This belief, however, runs counter to the available evidence. Contrary to popular opinion, homosexuals are not especially prone to make sexual approaches to children. One study charted the sexual arousal of samples of homosexual and heterosexual males to depictions of subjects of varying age. ${ }^{46}$ Both groups showed slight arousal to children; ${ }^{47}$ insofar as there was a difference, the heterosexuals showed more frequent and greater responses to young girls than did the homosexuals to correspondingly young boys. ${ }^{48}$ Additionally, clinical experience with child molesters suggests that a regression to pedophilic behavior following some frustration, by men who have had

41. Id. at 50 .

42. Id. at 49 .

43. Fernbach, Introduction to H. Heger, The Men with the Pink Triangle 1, 7-16 (1980). In the body of the work, Heger recounts his experience as a homosexual in a Nazi concentration camp.

44. Sen. Comm. on Expenditures in the Executive Departments, Subcomm. on Investigations, Employment of Homosexuals and Other Sex Perverts in Government, S. Doc. No. 241, 81st Cong., 2d Sess. 8-9, 19 (1950) [hereinafter Employment of Homosexuals].

45. D. MAXWell-FyFe, quoted in J. WeEks, supra note 37, at 159.

46. Freund, Assessment of Pedophilia, in Adult Sexual Interest in Children 139 (M. Cook \& K. Howells eds. 1981).

47. Id. at 162 .

48. Id. at 163 . 
successful sexual relationships with adults, is rarer among homosexuals than heterosexuals. ${ }^{49}$

One reason for the widespread impression that homosexual males seduce young boys may be that different standards are applied to the age gaps between heterosexual and homosexual lovers. Because of differences in the legal age of consent for homosexual and heterosexual contacts (twenty-one and sixteen respectively in Britain), ${ }^{50}$ a relationship between heterosexuals that would be legal and socially acceptable would be criminal and unacceptable in the case of a male couple. The demand for sexually mature teenage girls as prostitutes ${ }^{51}$ and advertising models must mean that they are physically attractive to a great many men, but an interest in boys of similar age on the part of homosexual men seems more perverse.

The availability of homosexual youths for contacts with older partners may have been encouraged by the extensive coverage of homosexuality in the modern media. In the days when boys from affluent English homes were sent to sex segregated boarding schools, accounts of school life reveal much homosexual activity between peers. ${ }^{52}$ At the time of Oscar Wilde's trial for homosexual acts, a well-known newspaper editor commented that at England's most prestigious schools, boys are free to pick up tendencies for which they may be sentenced to hard labor later on. ${ }^{53}$ Sexual horseplay and masturbatory displays and competitions in dormitories were commonplace. ${ }^{54}$ The participants in these early manifestations of sexual exuberance did not label themselves homosexuals, and evinced the usual fascination for girls when the opportunity arose. ${ }^{55}$ The minority for whom homosexual acts carried a deeper and perhaps more emotional significance did not stand out as deviants until later, when they failed to form heterosexual attachments. Today, however, with frequent reference to the topic on television, children cannot fail to become aware of homosexuality and the social stigma attached to it. In the early days of "gay liberation," many homosexuals complained that groups established to make life better for them did more harm than good by calling attention to behavior that was safest when unnoticed. ${ }^{56}$ One might expect same sex contacts to be viewed more critically by the youthful peer

49. Groth \& Birnbaum, Adult Sexual Orientation and Attraction to Underage Persons, 7 Archives of Sexual Behav. 175, 180 (1978); Newton, Homosexual Behavior and Child Molestation: A Review of the Evidence, 13 AdOLESENCE $29,40(1978)$.

50. Sexual Offences Act, 1956, 4 \& 5 Eliz. 2, ch. 69, § 6; Sexual Offences Act, 1967, ch. 60, $\S 1(1)$

51. C. Winick \& P. Kinsie, The Lively Commerce: Prostitution in the United States 31 (1971); see generally G. Sereny, The Invisible Children: Child Prostitution in America, West Germany and Great Britain (1984).

52. See, e.g., Waugh, The Romantic Friendship, in Eros: An Anthology of Friendship 414-15 (A Sutherland \& P. Anderson eds. 1975) [hereinafter Eros]; Shelley, Shelley's Childhood Friend, in Eros, supra, at 416; Hunt, Autobiography, in Eros, supra, at 417; Disraeli, Millbank and Coningsby, in Eros, supra, at 417-19; J. AdDington SYMONDs, supra note 26, at 94-96.

53. Stead, Review of Reviews, June 15th 1895, cited in R. Tannahill, SeX in History 381 (1980).

54. G. Westwood, A Minority: A Report on the life of the Male Homosexual in Great BRITAIN 25-26 (1960).

55. Id. at 27 .

56. T. Marotta, The Politics of Homosexuality 15 (1981). 
group these days, so that youngsters who desire homosexual contacts may look elsewhere than their schoolfellows to find satisfaction.

Accounts recently collected in a British survey in which an unselected sample of males described their early experiences of unsolicited homosexual propositioning or approaches, illustrated typical attitudes of boys towards homosexual behavior. ${ }^{57}$ Upon recognizing the true motive of a homosexual propositioner, the usual response was immediate withdrawal from an embarrassing and anxiety provoking situation. ${ }^{58}$ Some indication of the pressures that may in part account for why some boys are ready to have contact with older males emerged from another recent English survey of selfidentified homosexual men. ${ }^{59}$ Many of those interviewed recalled boyhood encounters with adults in public lavatories and outdoor cruising areas. ${ }^{60}$ They explained that because they were young, without money, too restricted by parents to be able to make journeys to distant gay bars, and wary of revealing their sexual inclinations to unsympathetic schoolfellows, they had no other opportunities for sexual contacts open to them at the time. ${ }^{61}$ Thus, it is not surprising that a recent survey of young homosexuals in London (where 62 percent of the men surveyed had their first homosexual experience under the age of sixteen, and 87 percent under the age of eighteen ${ }^{62}$ ) found that these youths' first partners were often considerably older than them (42 percent over twenty-one ${ }^{63}$ ).

\section{Promiscuity}

Long ago a British Quaker pamphlet suggested that a loving, faithful relationship should not be condemned simply because the partners are of the same sex.64 Male homosexuals, however, are renowned for casual, promiscuous encounters rather than stable relationships. ${ }^{65}$ For instance, until the menace of AIDS modified behavior, men patronizing gay saunas in the large cities of the Western world were accustomed to making sexual contacts of one sort or another with dozens of others during a single visit. ${ }^{66}$ The habit of swift, anonymous contacts in men's lavatories seems even more distasteful. ${ }^{67}$ In England, where saunas have been unusually strictly policed,

57. D.J. West \& T. Woodhouse, Sexual Encounters Between Boys and Adults (at press).

58. Id.

59. N. Thompson, D.J. West \& T. Woodhouse, Socio-Legal Problems of Male Homosexuals in Britain, in Sexual Victimisation: Two Recent Researches into Sex Problems and Their Social Effects 114-15 (1985) [hereinafter Sexual. Victimisation].

60. Id. at 136 .

61. Id.

62. L. Trenchard \& H. Warren, Something to Tell You ... The Experiences and Needs of Young Lesbians and Gay Men in London 133 (1984) [hereinafter Something to Tell You].

63. Id.

64. A. Heron, Towards a Quaker View of Sex: An Essay By a Group of Friends 26 (1964).

65. See generally A. Bell \& M. Weinberg, Homosexualities: A Study of Diverstry Among Men AND WOMEN (1978) [hereinafter HoMosexualities].

66. M. Hoffman, The Gay World: Male Homosexuality and the Social Creation of Evil 48-50 (1968).

67. R. Humphries, Tearoom Trade: Impersonal Sex in Public Places 1-15 (1970). 
gotivities in public lavatories have led to numerous criminal convictions for indecency and importuning. ${ }^{68}$ The habit of picking up perfect strangers for sexual purposes exposes homosexuals to blackmail and robbery. ${ }^{69}$

There are many possible reasons for these promiscuous tendencies. Since lesbians are less promiscuous than male homosexuals, ${ }^{70}$ it might be that masculinity, regardless of sexual orientation, is linked to promiscuity. A homosexual male eager for sexual adventure and conquest does not have to contend with feminine reluctance to participate in casual sex. Some of the propaganda of gay liberation favors the notion of gaining freedom from conventional heterosexual mores and family ties and enjoying more open sexual relationships. ${ }^{71}$ On the other hand, the many homosexual men who might like monogamous, marital style living are given little encouragement. The disapproval of men living together is reflected in difficulties with landlords and housing authorities and in discrimination in employment when a homosexual life style becomes apparent. ${ }^{72}$ Absence of the contractual obligations of marriage and the reponsibilities of child rearing facilitates the break up of a homosexual partnership if the relationship becomes strained. Whereas recognition and moral support from the extended family often helps cement a marriage, a homosexual partnership may have to withstand disapproval or ostracism from relatives. As a later Quaker pamphlet points out, promiscuity and short lived affairs may well be, at least in part, a consequence of intolerance. ${ }^{73}$

\section{Sexually Transmitted Diseases}

Although the fact has hitherto not been much publicized, male homosexuals, because of their promiscuity and their partiality to anal intercourse, have long been particularly vulnerable to sexually transmitted diseases. ${ }^{74}$ In 1980 and 1981, one study estimated that almost half of all reported cases of syphilis in the United States were attributable to same sex contacts. ${ }^{75}$ In Britain and the United States, homosexual males tested in venereal disease clinics have the highest prevalence of hepatitis $B$ infection of any group so far studied. ${ }^{76}$ The causal virus is found in the gastro-intestinal tract and is most likely to be acquired through penetration of the anus by

68. Walmsley, Indecency between Males and the Sexual Offences Act, 1967, CRIM. L. REv., July, 1978, at 400-07.

69. Sexual Victimisation, supra note 59, at 126. See also H. Montcomery Hyde, supra note 36 , at 254-56; EMPLOYMENT of Homosexuals, supra note 44, at 3-4.

70. Hомоsexualities, supra note 65 , at 93.

71. See, e.g., J. Gough \& M. MacNair, Gay Liberation in the Eighties 57.73 (1985).

72. P. Crane, Gays and the Law 99, 139-42 (1982).

73. D. Blamires, HomoseXualty from the Inside (1973).

74. Fulford, Caterall, Hoinville, Lim \& Wilson, Social and Psychological Factors in the Distribution of STD in Male Clinic Attenders: III Sexual Activity, 59 Brit. J. Venereal Diseases 386, 387-90 (1983).

75. Felman, Syphilis, in Sexually Transmitted Diseases in Homosexual Men: Diagnosis, Treatment, and Research 37, 41 (D. Ostrow, T. Sandholzer \& Y. Felman eds. 1983) [hereinafter STD].

76. Ostrow \& Gayle, Viral Hepatitis, in STD, supra note 75, at 107, 118. 
penis or tongue. ${ }^{77}$ Because of the long incubation period, ${ }^{78}$ and "long remission periods between manifestations of the illness, ${ }^{79}$ the number of infectious carriers greatly exceeds the number of diagnosed cases. ${ }^{80}$ Anal sexual practices are also associated with ameobic intestinal infestations and shigellosis, a form of bacilliary dysentery. ${ }^{81}$

The infecting organisms in all these diseases, including AIDS, have no connection with sexual orientation, but promiscuity and anal sex encourage their spread. It is probably an historical accident that AIDS was first identified in the homosexual community in America. ${ }^{82}$ In Africa, where the epidemic is thought to have originated, the disease is widespread in the heterosexual population of both sexes. ${ }^{83}$ Although anal intercourse carries a special risk, the virus is also transmitted by vaginal intercourse. 84 In Britain, the group with the highest known incidence of $\mathrm{HIV}$ antibody positive reactions (indicative of exposure to the infection) is not homosexuals, but hemophiliacs. This is because they were, until recently, dependent upon receiving blood products from infected American sources. ${ }^{85}$ Intravenous drug users who share syringes are believed to have been responsible for 'a rapid spread of AIDS in certain towns, notably Edinburgh. ${ }^{86}$ In addition, bisexuals and married men who indulge covertly in anonymous, casual homosexual contacts provide a further channel of transmission between the heterosexual and homosexual communities.

The British Government has recognized that its heterosexual majority may not remain shielded from infection for long. Britain has taken the unprecedented step of spending $£ 20,000,000$ on an explicit advertising campaign; directed to all sexually active people, warning of the dangers of multiple sexual partners and advising the use of condoms to lessen the risk. ${ }^{87}$ In stigmatizing the disease the "gay plague" and fulminating against the immorality of homosexuals, the tabloid press have encouraged a false sense of security among heterosexuals, which the government campaign may help to dispel. Since unrestrained promiscuity and unprotected sexual penetration risk spreading AIDS, it is these practices and not homosexuality as such at which the British Government's propaganda is directed. This pragmatic

77. Id. at 120 .

78. The average incubation period is 75 days, but can range from 50 to 180 days. Id.

79. Perillo, Campbell, Sanders, Regenstein \& Bodicky, Spontaneous Clearance and Reactivation of Hepatitis B Virus Infection Among Male Homosexuals with Chronic Type B Hepatitis, 100 ANNALS InTERnaL MED. 43, 46 (1984).

80. Ostrow \& Gayle, supra note 76 , at 121 .

81. William, Shigellosis, in STD, supra note 75, at 103.

82. See Understanding AIDS: A Comprehensive Guide 10-19 (V. Gong ed. 1985).

83. Id. at 17.

84. Biggar, The AIDS Problem in Africa, 1986-1 LANCET 79, 81.

85. Smithies, Acquired Immune Deficiency Syndrome (AIDS) HTLV III/LAV: The Causal Agent and Modes of Transmission, 18 Health TREnds 19, 21 (1986).

86. Woman's Hour (BBC broadcast, Dec. 23, 1987).

87. In the UK the Department of Health posted their explanatory leaflet to every household in the nation. The British Medical Association produced a more detailed, popular guide. BRITISH Medical Association, AIDS and You: An Illustrated Guide (March 1987). 
stance is deplored by many who would prefer a morality based campaign condemning all expression of sexuality outside monogamous, heterosexual marriage. 88 Others would like to target the attack more directly by recriminalizing the main source of contamination-homosexual behavior.

The homosexual community has already been alerted to the menace of AIDS by discussions in specialist gay publications and organizations. In England, the Terence Higgins Trust, a charitable organization started by gay men and based in London, is active in issuing literature and providing speakers for lectures and broadcast programs on AIDS. Many towns now have an AIDS Helpline, a telephone number that can be called by anyone wanting advice about AIDS.

Changes in homosexuals' habits have been most apparent in places such as San Francisco and New York, where the incidence of AIDS had been particularly high and where bath houses have been closed and gay bars converted to different usage. Systematic survey has revealed dramatic reductions in promiscuity among gay men and increasing use of safe sex techniques, largely mutual masturbation. ${ }^{89}$ These changes have been accompanied by a significant slowing down of the spread of AIDS. ${ }^{90}$ Unfortunately, because it sometimes takes years for an infected person to develop the illness, these changes cannot have an immediate impact on the incidence of AIDS deaths.

They could have a swifter effect in Europe where, according to statistics released by government departments, the disease is as yet less prevalent than in America.91 In Britain, by June 1987, according to Department of Health returns, there were 870 known cases of AIDS, of whom 490 had died. However, identified carriers already numbered over 6,000, and there are gloomy forecasts ${ }^{92}$ that AIDS illnesses may overwhelm the health services in Britain as they have already overwhelmed those in parts of Africa. ${ }^{93}$

The terror of AIDS may be thought to justify classifying homosexual behavior as crime because it is the main source of the disease. This argument has only superficial plausibility. The virus spreads by unprotected and promiscuous sexual contact and blood contamination, and heterosexuals are not immune. If legislation has to be introduced on public health grounds it should be directed against deliberately irresponsible acts committed by either

88. Longley, Catholics Agree to Contraception Advertisements, The Times (London), Dec. 6, 1986, at 1, col. 2.

89. Martin, The Impact of AIDS on Gay Male Sexual Behavior Patterns in New York City, 76 AM. J. PUB. HeAlTh 578, 581 (1987).

90. Winkelstein, Samuel, Padian, Wiley, Lang, Anderson \& Levy, The San Francisco Men's Health Study: III. Reduction in Human Immunodeficiency Virus Transmission among Homosexual/Bisexual Men, 198286, 77 Ам. J. Pub. Health 685, 686-87 (1987).

91. Lifson \& Curran, Epidemiology of AIDS: Current Trends and Prevention, in 1 Current Topics IN AIDS 7, 7-11 (1987). According to the American Center for Disease Control, there were 22,635 known cases of AIDS in the United States by July 14, 1986 (compared with only 548 in the U.K. by October, 1986).

92. Office of Health Economics, The AiDS Virus: Forecasting Its Impact (N. Wells ed. 1986).

93. Francis \& Quinn, AIDS in Africa, in 1 CuRRENT Topics IN AIDS 277, 277-79 (1987). 
homosexuals or heterosexuals, such as the concealment of a known infection from a new sex partner or the practice of prostitution while infected.

\section{IV}

\section{The Relationship Between Law and Public Attitudes}

Protagonists of gay rights seek to extend the reach of fundamental human freedoms to sexual expression and choice of sexual partner. Many argue that actions taken against homosexuals are in breach of Article 8 (respect for private life) or Article 14 (sex discrimination) of the European Convention on Human Rights. In October 1981, the European Court ruled on the case of Dudgeon $v$. $U K,{ }^{94}$ confirming that a police search of a man's home for drugs, followed by interrogation about personal letters discovered there which revealed evidence of homosexuality, violated Article 8. On March 13, 1984, the European Parliament passed a resolution urging member states to apply the same age of consent for homosexual and heterosexual acts and calling upon the European Commission to submit proposals to prevent discrimination against homosexuals in access to employment. ${ }^{95}$ Discussion about antidiscrimination laws continues in Europe as it does in the United States. In 1981, the Norwegian Parliament was the first in Europe to make it illegal to threaten publicly or hold in contempt a person or group, or to refuse the use of facilities, on the grounds of homosexual orientation and way of life. ${ }^{96}$

With a few notable exceptions (for example, the Soviet Union, Eire, Rumania, Cyprus, and parts of Yugoslavia), European countries, including those in Eastern Europe, do not criminalize voluntary adult homosexual behavior. Bit by bit, more and more countries are adopting a tolerant approach. Britain decriminalized homosexual behavior in 1967.97 More recently, France equalized the penalties for homosexual and heterosexual activity with minors in $1982,{ }^{98}$ and New Zealand decriminalized homosexual behavior after age eighteen in 1986 .

In contrast to these trends, in 1986 the Supreme Court of the United States, considering a challenge to the constitutionality of Georgia's criminalization of consensual sodomy, decided that there is no fundamental right to engage in sodomy, and that rights of privacy do not extend to male homosexual behavior. ${ }^{99}$ In Britain and the United States, there are no national legal measures to combat discrimination against homosexuality; when they have been advanced at local levels they have been bitterly contested. ${ }^{100}$

94. Dudgeon v. U.K., 3 European Human Rights Reports 40, 59 (1981)

95. 27 O. J. Eur. Comm. (No. C. 104) 48 (1984).

96. Penal Code of Norway $\$ 135 \mathrm{~A}$.

97. Sexual Offences Act, 1967 , ch. $60, \S 1$.

98. French Law No. 82-683 of 4 Aug. 1982

99. Bowers v. Hardwick, 106 S. Ct. 2841 (1986).

100. Meeker, Dombrink \& Geis, State Law and Local Ordinances in California Barring Discrimination on the Basis of Sexual Orientation, 10 U. Dayton L. Rev. 745, 756-57 (1985). 
(1) The contrasting and conflicting approaches to the legal and administrative control of homosexuality to be found all around the world are starkly set out in Pink Book, a compilation by the International Association of Lesbians/Gay Women and Gay Men (IGA), a homophile organization. Pink Book lists information on social and legal oppression and liberation in some one hundred different countries. ${ }^{101}$ In Iran, homosexual acts between males are punishable by death, and between women by a hundred lashes. ${ }^{102}$ In Saudi Arabia, a first violation is punishable by imprisonment and lashing, a repeat violation by death by decapitation. ${ }^{103}$ In Thailand the criminal code makes no mention of homosexuality, and social attitudes are relatively tolerant, but the large numbers of homosexual tourists taking advantage of the sexual availability of young persons has resulted in social disruption. ${ }^{104}$

In some countries, the attitudes of authorities are ambivalent. In Israel, for example, although the law forbids homosexual acts, homosexuality is rarely prosecuted, unless minors are involved. ${ }^{105}$ The Israeli army, with its pressing need for manpower, no longer excludes homosexuals from conscription. ${ }^{106}$ Police, however, harass gay men at their meeting spots and public disapproval is intense. ${ }^{107}$ In the Soviet Union, in addition to the traditional community intolerance, ${ }^{108}$ the KGB has made a practice of trying to discredit political dissidents by accusing them of homosexuality. The European Parliament, in a resolution on human rights on May 17, 1983, 109 called for the cessation of this tactic and condemned the Soviet Union for arbitrary interference with citizens' privacy. It could be, however, that even in the Soviet Union the justifiability of criminalizing consensual homosexual behavior will become the subject of more open debate in the future.

Christian teachings generally condemn homosexual behavior. The Vatican, in October 1986, reaffirmed its absolute condemnation of homosexual acts and the promotion of gay rights. When the constitutional validity of Ireland's antihomosexual legislation was challenged by a lecturer at Trinity College, Dublin, the Supreme Court of Eire held that state laws of Christian countries should support the prohibition of homosexual acts. ${ }^{110}$ Where Christianity prevails there is noticeably greater demand for the legal enforcement of religious rules on male homosexuality than for enforcement of the rules against lesbianism, fornication, and adultery. There is not complete unanimity, however, among the religious on the sinfulness of

101. International Association of Lesbians/Gay Women and Gay Men, Pink Book: A Global View of Lesbian and Gay Oppression and Liberation (1985),

102. Id. at 149 .

103. Id. at 164. While homosexual acts are forbidden by the Koran, and are believed contrary to human nature, these severe criminal penalties are imposed only in exceptional cases. Id.

104. Id. at 170 .

105. Id. at 66-67.

106. Id. at 70 .

107. Id. at $68 \cdot 70$.

108. M. Stern \& A. Stern, Sex in the USSR 214-21 (M. Howson \& C. Ryan trans. 1981).

109. 26 O. J. Eur. Comm. (No. C 161) 70 (1983).

110. Norris v. Attorney General, 1984 I.R. 36 (Ir. S.C.). 
homosexuality. Some might argue that sexual orientation, like skin color or gender, is a God-given attribute and that human beings in all these categories should be respected equally.

Exposed to conflicting messages from leadership figures, ordinary parents follow their own inclinations as heterosexuals when confronted with the possibility of their children becoming homosexuals. Two recent surveys found a considerable incidence of rejection by parents of offspring who disclosed their homosexuality. ${ }^{\prime \prime}$ In the inquiry among young homosexual Londoners, half of the young men, and an even larger proportion of young women, reported unfavorable parental reactions, amounting sometimes to complete withdrawal of love or even physical violence. ${ }^{12}$ Some 11 percent reported having been expelled from their homes. ${ }^{113}$ Most parents become more or less reconciled to the situation in time, but many remain regretful or inclined to blame themselves for having reared a homosexual.114 Reconciliation between father and son appears particularly difficult, especially if the son fails to conform to social expectations of masculinity. Many young homosexuals move away from home as soon as they can in order to pursue their own way of life, undergoing partial estrangement from their family to escape painful confrontations.

The acquisition of sexual information, and the development of confidence in their own sexuality, is a difficult process for the young heterosexual; for the homosexual it is much worse. Sex education in schools tends to be somewhat remote from a homosexual's personal needs. It is more explicit about the anatomy of intercourse and insemination than about emotions, techniques of stimulation, masturbatory habits, and practical sociosexual skills. ${ }^{115}$ This is because really open discussion between adults and children on these topics still causes embarrassment and also because teachers must bear in mind the varied standards of behavior expected of children from different ethnic, religious, or social class backgrounds. It is understandable that there should be a special reserve about homosexuality or a jokingly dismissive response if the matter is raised. This can add to the worries of a young person beginning to dread being "one of them" or perhaps already suffering family rejection. In the young Londoners' survey, one in five of the homosexual subjects, both male and female, reported having at some time attempted suicide on account of their sexuality. 116

A further complication has arisen through the publicity given recently to sexual abuse of children. A spate of academic books and papers on the subject was followed by newspaper articles and television programs. ${ }^{117}$ One

111. Sexual Victimisation, supra note 59; Something to Tell You, supra note 62.

112. Something to Tell You, supra note 62, at 45-51, 146-47.

113. Id. at 151 .

114. Id. at 32-45.

115. S. Jackson, Childhood and Sexuality 136-38, 145, 149-50 (1982).

116. Something to Tell You, supra note 62, at 151 .

117. For example Esther Ransen's popular BBC TV program "That's Life" has presented cases of child sexual abuse and sponsored the Childline telephone service for abused children. 
result has been the introduction of books and videos aimed at young children advising how to "Say No!" to inappropriate touches or approaches by adults. ${ }^{118}$ The main focus of concern has been small girls molested or seduced by fathers or other male adults in the household, but some well publicized surveys have revealed that a great many boys are also the subject of sexual attentions from adult males. ${ }^{119}$ The instructions to children naturally included both boys and girls, so now the first thing a boy is likely to be taught about homosexuality comes in the form of warnings against wicked homosexual pedophiles.

Law often lags behind social awareness of the need for reform, but sometimes it can take a lead, heeding informed judgment rather than popular clamor. An example is the British legislature's resistance to the reintroduction of capital punishment despite the belief that the majority of the population would welcome it. Many sophisticated persons, well informed on the subject, view the popular antipathy to homosexuality as a cruel and irrational prejudice which the law should resist rather than support. Strong dislike, in the absence of more compelling reasons, cannot justify the prohibition of something of great value to many.

Law influences public opinion. Following the decriminalization of male homosexuality in England, the public became more tolerant. In 1963 before the change in the law, a poll of adult opinion conducted by the Albany Trust (a charity concerned with sexual problems) showed that 63 percent did not want homosexuality to be made legal. By 1977, ten years after decriminalization, but before the advent of AIDS, a Gallup poll showed only 22 percent in favor of making homosexual relations illegal. ${ }^{120}$ The law may advance public tolerance by abolishing statutes that seek to control homosexual relationships differently and more strictly than the regulation of heterosexual relations. The age of consent should be the same, and sexual assault, pedophilia, prostitution, and public indecency should all be similarly defined and punished without regard to whether the misconduct is heterosexual or homosexual. The policy of tolerance should extend as far as possible into matters of civil rights and status. Exclusion from the armed forces, from government employment, and from the teaching and medical professions should be allowed only in cases in which one's homosexuality presents a demonstrable disadvantage. Legal recognition of long term homosexual cohabitations, where the couple want a binding contract, might help prevent some of the sad situations that occur when one partner dies and

118. M. Elliot, Preventing Child Sexual Assault: A Practical Guide to Talking with Children (1985). The author has sponsored videos such as Strong Kids, Safe Kids for use in schools. Some authorities consider the effort misplaced. See, e.g., Tucker, A Panic Over Child Abuse, 74 New Soc. 96,96 (1985).

119. For instance the poll by MORI; see Baker \& Duncan, Child Sexual Abuse: A Study of Prevalence in Great Britain, 9 Child Abuse \& Neglect 457-67 (1985).

120. Sexual Behaviour and Attitudes and Their Implications for Criminal Law (Council of Europe 15th Criminological Confeence, Strasbourg, 22-25 Nov. 1982) (citing Campaign for Homosexual Equality, QueErs Need Not APPly (1979)). 
his estranged relatives suddenly appear to claim his possessions or contest his will. Surveys of children adopted by homosexuals have not revealed many disasters, ${ }^{121}$ but some reserve seems justified in placing children in situations where they might become the victims of social suspicion. Official antidiscrimination could lessen social prejudice and do something to help relieve the distress experienced by young people when their sexual responses fail to conform to majority expectations, and to discourage parental rejection of homosexual children.

\section{$\mathrm{V}$}

\section{The Extent of Popular Disapproval}

Behavior generally disapproved, one might argue, should be banned regardless of whether it causes demonstrable harm. A particularly strong public feeling against homosexual practices, the argument continues, might alone suffice to justify prohibition of those practices. This argument undoubtedly reflects the fear that if the law falls too far out of line with the views of the majority, individuals may be tempted to take it upon themselves to suppress activities they find offensive. It is important to determine, therefore, the extent of public disapproval of homosexuality.

A considerable number of people strongly disapprove of homosexual behavior. According to a British survey, in 1983, 50 percent of the British populace endorsed the statement that "homosexual relationships are always wrong," and another 12 percent felt that homosexual relationships are "mostly wrong." 122 Figures from the United States indicate that even more Americans ( 75 percent) endorsed the view that homosexual relationships are wrong. ${ }^{123}$ Proposals implying equality between heterosexual and homosexual lifestyles met nearly unanimous disapproval. For instance, over 90 percent of the British respondents agreed that male homosexual couples should not be allowed to adopt children under the same conditions as other couples. ${ }^{124}$

In 1986, when education in schools was under discussion in Parliament, a heated public controversy arose over allegations that certain labor dominated local authorities were encouraging schools to inform children about homosexuality and to suggest that a homosexual lifestyle was perfectly acceptable. Parents became concerned and in the London Borough of Harringey a parents' rights group, protesting what they considered the promotion of homosexuality in schools, organized a boycott, keeping their children at home pending appropriate assurances. Antagonism towards the perceived encouragement of gay rights by some local authorities culminated

121. Golombok, Spencer \& Rutter, Children in Lesbian and Single-Parent Households: Psychosexual and Psychiatric Appraisal, 24 J. Child Psycholocy \& Psychiatry 551, 55 1-72 (1983).

122. Airey, Social and Moral Values, in British Social Attitudes, The 1984 Report 121,137 (R. Jowell \& C. Airey eds. 1984).

123. Id.

124. Id. at 139. The survey also revealed that only about half of the British population considers it acceptable for homosexuals to be teachers or to hold responsible public positions. Id. at 138-39. 
in December 1987. A Conservative Member of Parliament proposed an amendment to the Local Government Bill inserting a clause to forbid local authorities to "promote homosexuality" or to promote the teaching in any maintained school of acceptability of homosexuality as a pretended family relationship. With government support the measure was,passed in the House of Commons by a vote of 308 to 215 .

Most disturbingly, the intensity of some individuals' distaste for homosexual behavior has resulted in violence. In one survey, one hundred English male homosexuals were interviewed about their social problems; forty-nine reported having been assaulted on one or more occasions on account of their homosexuality. ${ }^{125}$ Most of these assaults were either attacks by "queer bashers," who hang about gay meeting places in order to waylay and beat up homosexuals, or were incidents in bars or other places where men observing overtly homosexual conversation or gestures were outraged to the point of violence. Men on trial for homicide have occasionally pleaded successfully, and perhaps truthfully, that they were provoked to understandable fury by their victims' alleged homosexual approaches. For example, in Regina $v$. Pellicci, ${ }^{126}$ the defendant, charged with murder, had battered to death a former employer and then burned the body. He said he had done so in a fit of uncontrolled emotion following homosexual advances by the victim. He was found guilty of manslaughter.

The advent of the Acquired Immune Deficiency Syndrome (AIDS) epidemic has greatly hardened public attitudes against homosexuality. For the first time in many years man is confronted by a fatal venereal disease for which there is as yet no effective cure or vaccine. Many see AIDS as God's punishment for vice. ${ }^{127}$ In December 1986, the Chief Constable of Greater Manchester, England (a popular figure who achieved a high rating in the British Broadcasting Company's postal vote for "man-of-the-year"), made a forthright speech, widely quoted and commented upon in the press, condemning homosexuals and prostitutes for spreading AIDS. ${ }^{128}$

\section{VI \\ Conclusions for Social Policy}

The empirical findings reviewed briefly in this paper lend no support to the belief that homosexual orientation, or the generality of homosexual behavior, causes substantial harm. Pragmatic considerations, however, cannot provide definitive solutions to the moral issues and conflicts of interest involved. Social and legal policy demand a choice among conflicting values,

125. Sexual Victimisation, supra note 59 , at 123.

126. The author suggests that the reader see The Times, June 14, 1986, for an account of the facts of Regina v. Pellicci.

127. D.J. West, Sexual Crimes and Confrontations: A Study of Victims and Offenders 122 (1987).

128. The author recalls that this speech received widespread attention in Britain and suggests that The Times, Dec. 12, 1986, may contain some account of the speech. 
balancing freedom for the individual against the interests and wishes of society at large.

It is morally wrong, unnecessarily harsh, and practicably unattainable to use the criminal law to suppress all homosexual relationships. Criminalization driives the problem underground, discouraging rational discussion. It forces many into pretense, leaving them vulnerable 'to blackmail, discrimination, and exploitation. Criminalization alienates homosexuals from mainstream values, unnecessarily diminishing their potential for contributing to society. A better solution would be a policy of tolerance and nondiscrimination, either along the lines advocated by the European Parliament, ${ }^{129}$ or by the English Howard League. Following the recommendations of its Working Party on Unlawful Sex, the Howard League recently adopted the policy that sexual acts of any kind between freely consenting parties should only be a criminal offense where that is necessary to protect vulnerable individuals, such as children. ${ }^{130}$ It concluded that "[u]nlawful sexual behaviour should be similarly defined, and should attract similar penalties, regardless of whether the victims of the offenders are male or female."131

Homosexual and heterosexual lifestyles are not identical. The disadvantages of belonging to an unpopular minority and being unable to enjoy a conventional family life are apparent. Nevertheless, a humane and tolerant stance towards minorities, institutionalized in legislation, seems morally right and the mark of a truly civilized society.

129. See 27 O.J. Eur. Com. (No. 6.104) 48 (1984).

130. Howard League for Penal Reform, Unlawful Sex: Offences, Victims and Offenders in the Criminal Justice System of England and Wales 3, 162 (1985).

131. Id. at 162. See also West, Ignoring Gender in Sex Crimes, 5 CRIM. Just. 8-9 (1987). 
